\title{
Mental health service user and staff perspectives on tobacco addiction and smoking cessation: A meta- synthesis of published qualitative studies DOI:
}

10.1111/jpm.12458

\section{Document Version \\ Accepted author manuscript}

Link to publication record in Manchester Research Explorer

Citation for published version (APA):

Malone, V., Harrison, R., \& Daker-White, G. (2018). Mental health service user and staff perspectives on tobacco addiction and smoking cessation: A meta-synthesis of published qualitative studies. Journal of Psychiatric and Mental Health Nursing, 25(4), 270-282. https://doi.org/10.1111/jpm.12458

Published in:

Journal of Psychiatric and Mental Health Nursing

\section{Citing this paper}

Please note that where the full-text provided on Manchester Research Explorer is the Author Accepted Manuscript or Proof version this may differ from the final Published version. If citing, it is advised that you check and use the publisher's definitive version.

\section{General rights}

Copyright and moral rights for the publications made accessible in the Research Explorer are retained by the authors and/or other copyright owners and it is a condition of accessing publications that users recognise and abide by the legal requirements associated with these rights.

\section{Takedown policy}

If you believe that this document breaches copyright please refer to the University of Manchester's Takedown Procedures [http://man.ac.uk/04Y6Bo] or contact uml.scholarlycommunications@manchester.ac.uk providing relevant details, so we can investigate your claim.

\section{OPEN ACCESS}


Article type : Review Article

Mental health service user and staff perspectives on tobacco addiction and smoking cessation: A meta-synthesis of published qualitative studies

Short title: A meta-synthesis on smoking cessation

Malone Victoria ${ }^{1}$, Harrison Roger ${ }^{2}$ and Daker-White Gavin ${ }^{3}$

${ }^{1}$ St Vincent's Hospital, Sydney, Australia

${ }^{2}$ The University of Manchester, UK

${ }^{3}$ NIHR Greater Manchester Primary Care Patient Safety Translational Research Centre, The University of Manchester, UK

Corresponding author:

Mrs Victoria Malone

Address: Alcohol and Drug Service, St Vincent's Hospital, Level 4 O'Brien Centre, 390

Victoria Street, Darlinghurst, Sydney NSW 2010 Australia Tel: + 610432017663 Email:

Victoria.Malone@svha.org.au

This article has been accepted for publication and undergone full peer review but has not been through the copyediting, typesetting, pagination and proofreading process, which may lead to differences between this version and the Version of Record. Please cite this article as doi: $10.1111 /$ jpm. 12458

This article is protected by copyright. All rights reserved. 


\begin{abstract}
Introduction

People with mental illness are up to 3 times more likely to smoke and experience greater challenges and less success when trying to quit, therefore have higher risk of smokingrelated morbidity and mortality. There is a lack of evidence on successful interventions to reduce the smoking rates in people living with serve mental illness. A meta-synthesis was undertaken to summarise data from multiple studies to inform the development of future smoking cessation intervention studies.
\end{abstract}

\title{
Methods
}

MEDLINE, PsycINFO, Embase and CINAHL were searched in March 2017. A total of 965 titles and abstracts were screened for inclusion with 29 papers reviewed in full and 15 studies that met inclusion criteria. Included studies were assessed for quality using the Critical Appraisal Skills Programme (CASP) tool. Key data across studies were examined and compared and a thematic analysis was conducted.

\section{Results}

Analysis and synthesis developed five analytical themes: Environmental and social context, living with a mental health illness, health awareness, financial awareness, and provision of smoking cessation support. Themes generated the interpretive construct: "Whose role is it anyway?" which highlights tensions between staff perspectives on their role and responsibilities to providing smoking cessation support and support service users would like to receive.

\section{Relevance to Mental Health Nursing}

Routine smoking cessation training for mental health professionals and research on innovative smoking cessation interventions to support people living with mental illness is needed. The Cochrane tobacco group has not found sufficient direct evidence of existing evidence-based interventions that have beneficial effect on smoking in people living with 
mental illness. With this in mind mental health professionals should be encouraged to engage in future research into the development of new interventions and consider innovative harm reduction strategies for smoking into their practice, to reduce the morbidity and mortality many people living with mental illness experience from tobacco smoking.

Key words: Mental Health, smoking cessation, qualitative research, tobacco addiction

\section{Accessible summary}

What is known on the subject:

- There are high rates of tobacco smoking in people living with mental illness, rates are much higher than the general population.

- People living with mental illness experience high rates of cardiovascular disease and other physical health problems as a result of tobacco smoking.

- There is a lack of evidence on successful interventions for reducing the rates of smoking in people living with mental illness.

What this paper adds:

- A meta-synthesis of data from a number of studies to support mental health nurses to access data quickly and support the translation of findings into practice.

- Studies found staff working in mental health services expressed they did not have the confidence to adequately address smoking cessation for people living with mental illness.

- People living with mental illness would like support and encouragement support to help them achieve successful smoking cessation.

- People living with mental illness want support from mental health service staff to increase their confidence in smoking cessation rather than mainstream smoking cessation services.

This article is protected by copyright. All rights reserved. 
What are the implications to practice:

- Existing evidence based interventions for smoking cessation has had limited impact on the smoking rates of people living with mental illness.

- Research is needed into innovative smoking cessation interventions and the service delivery of these interventions for people living with mental illness.

- Interventions to support people living with mental illness in smoking cessation could be part of mainstream mental health service delivery.

- Opportunities for smoking cessation training for mental health service staff could be provided.

\section{Introduction}

Tobacco is the largest preventable cause of morbidity and mortality around the world causing an increased risk of cancers and cardiovascular disease (Mathers \& Loncar, 2006). The rate of tobacco smoking amongst persons with mental illness is three times that of the general population (Lasser et al., 2000), contributing to the high rates of morbidity and mortality experienced by this population. As a consequence, this exacerbates health inequalities (Ziedonis et al., 2008) for an already vulnerable group of people. The impact is no doubt far wider than health alone, as those experiencing mental illness spend as much as $30 \%$ of their monthly income on cigarettes (Steinberg, Williams, \& Ziedonis, 2004).

It is thought there are psychosocial and neurobiological factors that contribute to tobacco addiction. The mood altering effects of nicotine that has been shown to improve cognition, decrease appetite and elevate mood are thought to be key factors in the addictive reinforcement pathways in the brain (Prochaska, 2010). This has been found in the general population but has been found to be stronger related in people living with mental illness (Aubin, Rollema, Svensson, \& Winterer, 2012). People living with mental illness have been found to favour these mood altering effects of nicotine more than smokers from the general population (Spring, Pingitore, \& McChargue, 2003). Tobacco however is not effective at managing moods and stress as many smokers believe it is and has been proven to increase 
psychotic symptoms (Chad D Morris et al., 2011) and reduce the therapeutic blood levels of a number of psychiatric medications(Zevin \& Benowitz, 1999). Tobacco addiction has also unexplainably been shown to be one of the strongest predictors of future suicidal behaviours (Breslau, Schultz, Johnson, Peterson, \& Davis, 2005).

A mental health service users risk of tobacco-related disease, financial situation, clinical presentation and overall quality of life can be significantly improved within a few years of quitting (Filia, Baker, Gurvich, Richmond, \& Kulkarni, 2014). Although antismoking campaigns and smoking cessation programs have been successful in reducing smoking rates within the general population (Aubin et al., 2012), the rate of successful quit attempts is much lower in disadvantaged populations including those with mental illness (Hiscock, Bauld, Amos, Fidler, \& Munafò, 2012). Tobacco control policies and smoking cessation interventions aimed at the general population have not resulted in the same quit rates for people living with mental illness (Lê Cook et al., 2014).

A recent appraisal in 2017(Trainor \& Leavey, 2017), reviewed the quality of qualitative research looking at barriers and facilitators to smoking cessation among people with mental illness. The review focused on the quality of studies undertaken but failed to synthesise the results of the studies. Results from qualitative studies need to be synthesised to combine a broader range of participant views, using comparison and translation to build on findings and create new interpretations. This enables the results of qualitative studies to be more widely utilized and lead the qualitative research findings into the centre of evidence based practice (Sandelowski, 2004). Trainor \& Leavey did begin to uncover some key barriers and facilitators that included health provider support and smoking to manage mental health symptoms and provide a descriptive list of these findings. This meta-synthesis proves the reproducibility and verification of these findings and that these findings are true. This study also goes a step beyond listing descriptive themes to synthesising data into analytical themes. The findings from Trainor \& Leavey were limited to predominantly individual barriers to smoking cessation. This meta-synthesis opens exploration up to reasons for smoking and the culture of smoking within the history of mental health services.

Summarising the data from across studies to help mental health nurses think about solutions to care.

This article is protected by copyright. All rights reserved. 
The aim of this study was to gather data and findings from across a number of studies develop a better understanding of the perspectives of people with mental illness and those providing treatment and care. An up to date search and review of studies and a metasynthesis was undertaken to explore the facilitators for people with mental illness to continue to smoke and the facilitators to quit smoking. A meta-synthesis was undertaken to create a larger interpretive rendering of a sufficient number of qualitative studies undertaken on mental illness and tobacco smoking. This will enable results to contribute to the development of new interventions for future research leading to explicit, conscientious and judicious evidence for best practice.

\section{METHODS}

\section{Search strategy}

A detailed search strategy (figure 1) was developed and revised for the following databases MEDLINE, PsycINFO, Embase and CINAHL (Liberati et al., 2009). The initial searches were performed in July 2015 and repeated for new references in November 2016 and March 2017. The search was conducted using the following keyword search terms: 'Smoking', 'smoking cessation', 'mental health user', 'consumer', 'patient', 'patient perspective', 'staff perspective', 'provider perspective', 'patient', 'medical staff', 'mental disorders', 'mental illness', 'psychiatric'. Boolean operators 'AND' and 'OR' were used to connect and define between search terms. The keyword search terms were used for all fields' title and abstract for original peer reviewed articles published in English between January 1980 and January 2017. These dates were chosen to ensure all studies included in the Trainor \& Leavey appraisal that searched from 1980 to 2015 were found, plus more recent studies. Two authors VM and GDW performed parallel independent searches to avoid leaving out relevant articles. Title and abstract and full text screening was then conducted by VM and GDW in collaboration. In addition references of retrieved papers were searched for additional relevant papers by VM.

\section{Study selection criteria}

The review was aimed at exploring the perspectives of mental health service users and/or staff and was interested in studies that had collected data through interview, focus group, 
observation or ethnographic methods. The review did not take into account studies that had only collected data via quantitative methods. Decisions regarding inclusions and exclusions were only taken by consensus of authors VM, GDW and RH.

Studies were included if they met all of the following criteria: 1) the study was published in the English language, 2) the study explored the perspective of smoking and/or smoking cessation from either people living with mental illness or people working with people living with mental illness, 3) the study was published between 1980 and March 2017.

Studies needed to state in their inclusion criteria that participants had experienced mental illness and were over the age of 18 years old. If the study looked at professional's perspective, the study needed to report that participants had worked within a professional role with those experiencing mental illness in either an inpatient, outpatient or community setting.

\section{Data extraction}

Data included quotes provided from interviews and focus groups and was extracted by author VM in line with thematic synthesis. A standard extraction form was used (Munro et al., 2007) which included information on sampling methods, participant characteristics, data analysis approach and first and second constructs including author's interpretations and compiled into a data extraction table (Table 1).

\section{Data synthesis}

The development of descriptive themes from extracted data underwent a process of constant comparison (Glaser \& Strauss, 2009). Key data within and across studies was examined and compared between and within the studies allowing for regularities within the data to become apparent and emerging themes to be generated. Analytical themes were then developed by authors VM, GDW and RH using an inductive approach of building themes from empirical observations (Green \& Thorogood, 2009) and synthesis was achieved by interpreting groups of findings, regularities and emerging themes as extracted from included studies (Table 2).

This article is protected by copyright. All rights reserved. 


\section{RESULTS}

\section{Selection of studies}

The combined electronic searches identified 1,139 studies, 174 were excluded from the title, and 939 were excluded based on a review of title and abstract. Studies were excluded if they were not 1) written in English; 2) published between 1980 and 2017; 3) examining smoking or smoking cessation with people living with mental illness; and 4) using qualitative methods to gather data. 29 full texts were examined, of which 15 studies met inclusion criteria (Davis, Brunette, Vorhies, Ferron, \& Whitley, 2010; Dickerson et al., 2011; Esterberg \& Compton, 2005; Forchuk et al., 2002; Johnson, Moffat, \& Malchy, 2010; Kerr, Woods, Knussen, Watson, \& Hunter, 2013; Lawn \& Condon, 2006; Lucksted, Dixon, \& Sembly, 2000; Marques de Oliveira \& Furegato, 2014; Chad D. Morris, Waxmonsky, May, \& Giese, 2009; Nawaz et al., 2012; Prochaska et al., 2013; Rae, Pettey, Aubry, \& Stol, 2015; Snyder, McDevitt, \& Painter, 2008; Solway, 2011) for this meta-synthesis (Figure 1). The references of the 29 retrieved papers were examined but no further studies were found.

\section{Quality of studies}

The 15 studies meeting inclusion criteria were assessed for publication quality using the Critical Appraisal Skills Programme (CASP) for qualitative research (Table 3). CASP is a set of critical appraisal tools to help assess if research is reliable, trustworthy and relevant (CASP, 2006). CASP checklists help readers to ask if the research and recruitment methods used were appropriate, if analysis was significantly rigorous and if there is a clear statement of findings. All 15 studies were found to use appropriate qualitative methods for the study question; all explored tobacco smoking or smoking cessation from the perspective of those with mental illness or those who work professionally with persons with mental illness. No studies reflected and reported on how the researchers' personal bias could have affected the study results. Studies adequately referenced the relevant literature but few studies made the connection to an existing theory clearly. The lack of connection to theory can affect the 'synthesizability' of qualitative studies (Barnett-Page, Thomas, Barnett-Page, \& Thomas, 2009). Connecting findings to theories and concepts helps the research go beyond simply 'adding together' empirical findings. Integrating findings with theory enables the 
synthesis to contribute to the development of deeper insights and understanding of experience (Green \& Thorogood, 2009)

\section{Analysis}

The 15 included studies all shared common themes which then were developed and interpreted into analytical themes. 1. 'Environmental and social context' and 2. 'Living with a mental illness' were themes developed from exploring the facilitators which supported service users to continue to smoke. 3. 'Health awareness', 4. 'Financial awareness' and 5. 'Provision of smoking cessation support' were themes developed from exploring the facilitators to supporting service users to quit smoking:

\section{Environmental and social context}

The environments people with mental illness live in such as hostels and community housing are often populated with individuals who are heavily addicted to tobacco. Smoking within this environment was seen as socially acceptable and service users felt it hindered successful quit attempts. Psychiatric services were seen as environments in which smoking was often condoned and frequently supported. Staff admitted to rolling cigarettes for service users unable to do so themselves as an enticement to encourage good behaviour. The use of tobacco as a reward for good behaviour and compliance helped create a normalisation of smoking.

"Cigarettes were a currency. If you wanted the patients to do something, you could give them a cigarette and they'd probably do it. In fact, I can remember my first ward, the charge sister saying, 'Go and run this errand and I'll give you a cigarette'. It was how you got things done" (Staff participant; Lawn, Condon 2006)

Service users and staff expressed the view that smoking helped to overcome loneliness and boredom that smoking had often become a form of support.

"Just to have something else, something different to do" (Service user; Lucksted et al 2000)

Staff felt past experiences of aggression and agitated behaviour from service users around cigarettes was an example of why smoking cessation was not appropriate, commenting on the escalation of a service user's behaviour and an implicit view of the service user as a risk

This article is protected by copyright. All rights reserved. 
when they didn't have access to cigarettes. In turn the lack of encouragement towards smoking cessation had led service users to feel unsupported in making attempts to quit.

"Both from nurses' and client management perspective, if you can keep the ward running smoothly and minimizing the amount of aggression by allowing them to smoke, then allowing them to smoke facilitates that. By all means. I'd rather have a smooth running ward than go home with a broken arm" (Staff participant; Lawn, Condon 2006)

Staff working in secure settings felt service users had been deprived of many pleasures and cigarettes were seen as one thing service users found pleasurable and could still have. This was reflected by service users:

"Other people told me, 'Enjoy your cigarettes, it's the only thing you have...You don't really have that much in life'"' (Service user; Lucksted et al 2000)

Both staff and service users felt social relationships and pressure from peers influenced uptake and the continuation of smoking. A number of the studies discussed how smoking behaviour of friends and family had a strong influence on the smoking behaviour of service users and smoking cessation would have a negative impact on important social relationships in their life.

"If they [mental health service user] stop and their friends are all smoking, who do they hang out with?" (Staff participant; Morris et al 2009)

\section{Living with a mental illness}

Service users reported using tobacco as a form of self-medication to ease the symptoms of their mental illness and to control emotions. There was a general perception amongst service users across included studies that smoking helped relieve stress, depression, boredom, and loneliness. Service users expressed a fear that if they gave up smoking they would lose a coping strategy. When service users had succeeded in a time of smoking cessation they expressed experiencing a time of stress and a decline in their mental health which led them back to smoking again. Service users discussed being encouraged by staff to start smoking with advice that smoking would help with their symptoms of mental illness.

This article is protected by copyright. All rights reserved. 
"I more or less became a smoker because I was told it would help me with my illness. I was taught more about it helping my illness than I was about cancer and staff like that" (Service User; Morris et al 2009)

Service users prioritised concerns of the effects of smoking cessation would have on their mental illness symptoms over concerns continued smoking would have on their physical health. Staff felt pressure to meet the demands of service user's immediate mental illness symptoms rather than thinking about longer-term physical effects of smoking.

"I think they're less motivated and inclined to seek preventative health strategies, they're more worried about keeping well [mentally] on a day to day basis than looking after longterm [physical] health" (Staff participant; Kerr et al 2013)

Staff had concerns that looking at restricting service users' smoking whilst acutely unwell would hinder recovery and cause service users more suffering.

"We know that somehow tobacco use helps schizophrenia or psychiatric clients to cope with their symptoms" (Staff participant; Johnson et al 2010)

Service users expressed smoking helped with the side effects of psychiatric medication and felt that psychiatric medication increased their cravings for cigarettes

"We are already nervous, we came here with depression, if you take away the cigarette we get worse" (Service user; Marques de Oliveira R, Furegato ARF 2014)

The human rights for the freedom to make a personal choice about whether to smoke or not was a concern for both service users and staff.

"I want to keep smoking because I believe in individual freedom and even though the whole world is down on cigarettes, I want to be able to smoke" (Service user; Solway 2011)

Staff across studies were concerned about telling service users 'what to do' and maintaining a good relationship. They did not want to seem to be imposing their own value and judgements onto service users or taking away more choices from what little they had left, especially if the service user was an inpatient.

This article is protected by copyright. All rights reserved. 
"Regardless of their physical health they prioritise their cigarettes as they need this wee crutch, don't they. It's about choices and control, it's respecting the individual" (Staff participant; Kerr et al 2013)

Whether or not service users wanted to continue to smoke they did like staff talking to them about smoking cessation and felt it showed staff took an interest in their health and cared about them.

"It's like, the fact that someone's giving a half a shit about you, that was the biggest one. I felt accepted because someone was actually talking to me and not judging me" (Service user; Rae et al 2014)

Service users did not believe they could achieve smoking cessation and expressed finding it extremely hard. Service users did not see wellness and recovery as real possibilities in their lives, many expressed this had been impacted on by failed quit attempts and the difficulty in continued cessation.

"I'm not confident that I could stop. I badly need some confidence" (service user: Kerr et al 2013)

Staff related the lack of motivation to quit to the symptoms of the mental health disorder in which service users may experience.

"I think the motivation and willpower is probably more difficult. Motivation is a big issue anyway as part of their illness. You know lack of motivation, the ability to sustain things. Even with day to day stuff, motivation is a big issue" (Staff participant; Kerr et al 2013)

\section{Facilitators to quitting}

Eight of the fifth teen included studies included the perspective of service users who had successfully quit smoking and explored some of the facilitators to successful smoking cessation. Successful quit attempts had generally occurred after several unsuccessful quit attempts. Health awareness, financial awareness and the provision of smoking cessation support had contributed to the attempt to quit.

This article is protected by copyright. All rights reserved. 


\section{Health awareness}

Respiratory problems, heart disease or a smoking related death of a loved one were evident in impacting the decision to attempt smoking cessation by a service user.

"I started feeling pressure on my chest. I had pneumonia from smoking" (Service user; Dickerson et al 2011)

It was apparent that physical health was only a strong motivator to quit once the service user had experienced a physical health problem. Service users who did not yet have physical health problems were more apathetic about the connection.

"[Quitting] would help my health but I mean I don't have to worry about it too much. Okay because I mean its foregone conclusion that I am going to get F-king emphysema or bronchitis" (Service user; Rae et al 2015)

\section{Financial awareness}

The cost of cigarettes was found to be a motivator to successful quitting within studies including studies looking at service users of different ethnic origins.

I think that financial issues can be a motivator for a few. From past experience we had someone who saved $\$ 900$ once she stopped. She could see all the money adding up, which she found really good." (Staff participant; Kerr et al 2013)

\section{Provision of smoking cessation support}

Included studies found service users act on the information they have, which is often very little. Smoking cessation advice from professionals was found as a reason some service users quit and when given sufficient information on smoking, service users made the choice to look at their smoking. Service users often had misconceptions about nicotine replacement therapy or were not routinely offered it and they would have liked education about NRT from staff. Staff however felt they did not have the knowledge to provide smoking cessation information or how to provide nicotine replacement therapy nor was it their role to do so.

This article is protected by copyright. All rights reserved. 
"It's an addiction, so you need a lot of resources to help out with it. It would never be something that I could do. It's not like something else where I could help them, like by referring them to a job" (Staff participant; Johnson et al 2010)

\section{Interpretive construct}

The descriptive and analytical themes identified by the qualitative studies illustrate a tension between the perspectives of staff and service users about whose role smoking cessation support is. Staff felt it was not their role to support service users in smoking cessation but interestingly, support and advice from staff was seen as a key facilitator to quitting by service users leading to the construct "Whose role is anyway?". Whose role is it to provide smoking cessation support? Who is best placed to provide smoking cessation support to people living with mental illness? There has been some key work around the similar needs of physical health care for people with mental illness and the incorporation of service provision in mental health care settings (Mwebe, 2017). A survey conducted with mental health nurses and general nurses in England (McNally et al., 2006) found less favourable attitudes towards providing smoking cessation provision from mental health nurses. Further studies have found that mental health nurses recognise that physical health screening and health promotion activities are inadequate in mental health services (Hyland, Judd, Davidson, Jolley, \& Hocking, 2003) and that this gap in practice relates to staff shortages and lack of training and confusion around roles (Robson \& Gray, 2007). Staff perspectives from the studies in this review conveyed that there was little knowledge on the impact tobacco addiction had on mental health or of the positive impacts smoking cessation could have on a service user's recovery from mental illness. Staff expressed this restricted the support on smoking cessation they were able to provide.

\section{Discussion}

The objectives of this study were to review and create a synthesis of the qualitative literature on the perspectives of smoking and smoking cessation from people living with mental illness and mental health service staff. To conduct a meta-synthesis of findings to explore the facilitators to supporting mental health service users to quit and what the facilitators were to continue to smoke.

This article is protected by copyright. All rights reserved. 
The comprehensive search identified 15 studies relevant to this review. An earlier review conducted in 2016 (Trainor \& Leavey, 2017) had identified 11 studies, all but one are included in the study reported here. The one study was excluded due to looking at the perspectives of family members not people with mental illness or mental health service staff. This study also found facilitators to smoking around the environmental and social context. Consequently, the study here is the first to report on the synthesis of results from qualitative studies to explore and understand the phenomena of tobacco addiction and smoking cessation for people living with mental illness. This Meta synthesis provides a unique deeper interrogation and analysis of the qualitative data and provides findings that can influence policy and practice change which is vitally important if better service provision to reduce the disparity in care and mortality is to be achieved. People living with mental illness and mental health service staff hold an array of perspectives on smoking that centre around environmental, social factors and the symptoms of mental illness. What this metasynthesis adds primarily to the current discourse is that the combined overall impact of smoking and the difficulty of quitting in persons with mental illness has been impacted by the tension of different perspectives between service users and staff around the roles and responsibilities of smoking cessation support.

This study extends previous reviews of the literature through its extended time frame and its meta-synthesis of results. Nevertheless limitations must be acknowledged to this metasynthesis: Studies published before 1980 were deemed out of date and excluded, however the accounts of smoking and smoking cessation from studies previous to 1980 may have still added important data to capture the phenomenon of smoking and mental health (Jones, 2004). This meta-synthesis was also restricted to published literature, failing to address the area of grey literature which may have affected the ability to fully reflect existing evidence (Conn, Valentine, Cooper, \& Rantz, 2003) and created publication bias (Bondas \& Hall, 2007)

A vital barrier to be overcome if smoking cessation interventions are to be successfully implemented in mental health services is the lack of knowledge or confidence of mental health service staff. Smoking cessation training is not routinely offered to mental health professionals even though a large amount of rigorous research has found training of health professionals in smoking cessation to be effective(Carson et al., 2012). It has been suggested that training as part of a systems change approach including reorientation of

This article is protected by copyright. All rights reserved. 
environments and consistent enforcement of smoke-free policy would integrate the standardisation of smoking cessation support to mental health service users (Fiore, Keller, \& Curry, 2007) A policy directive from this study would be the focus on the implementation of routine training on tobacco addiction and smoking cessation for mental health professionals.

Across papers within this study there was identification of people living with mental illness who did not have a desire to quit. Consequently, previous approaches to smoking cessation would have limited impact overall. An alternative approach to be incorporated into smoking cessation policies considers that of 'harm reduction'. Harm reduction has been shown to be a promising policy option to tackle health inequalities in those from vulnerable populations, including people living with mental illness who are heavily addicted to nicotine with no interest in quitting (Shiffman et al., 2007). Research has shown when mental health service users were given harm reduction advice rather than advised to quit, $67 \%$ of participants who were not interested in quitting considered treatment (Bittoun, Barone, Mendelsohn, Elcombe, \& Glozier, 2014), which may ultimately lead them to go on and try to abstain from nicotine in the future. Harm reduction works on the principle of reducing the harm of cigarettes through the substitution of nicotine with such products as nicotine replacement therapy (Emma et al., 2013). Smokers can use nicotine replacement therapy and continue to smoke to gradually reduce cigarette consumption whilst lessoning initial anxiety associated with quitting (Stead \& Lancaster, 2007). What this study has found is that service users want support from mental health professionals around tobacco addiction but mental health professionals express a need for routine training to gain the knowledge and confidence to provide information, education and intervention. A Recent survey of Australian mental health professionals found that over half of mental health professionals have still not received any training in smoking cessation which subsequently has led to only a third of mental health professional delivering cessation assistance to service users (Sharma, Meurk, Bell, Ford, \& Gartner, 2017). Additionally smoking cessation assistance provided by professionals who have undergone smoking cessation training has been associated with better abstinence rates than when provided by untrained professionals (Carson et al., 2012). Further research is needed on innovative smoking cessation interventions for this population group and health service research into how to incorporate this into routine care.

This article is protected by copyright. All rights reserved. 
Future policy directive could focus on the implementation of routine smoking cessation training which includes tobacco harm reduction strategies.

\section{Implications for practice}

This meta-synthesis gives an understanding of the tensions between the perspectives of people living with mental illness and mental health service staff regarding facilitators to smoking and smoking cessation. Evidence presented in this review highlights some of the barriers of staff attitudes based at times on outdated and anecdotal views, rather than up to date evidence of mental health service users desires to stop smoking and evidence of smoking cessation support for people with mental illness. Consequently, vulnerable individuals are being denied direct and indirect support to reduce the harm of smoking morbidity and mortality. Tackling normalisation of smoking for people with mental illness, supporting the implementation of routine training in nicotine addiction for mental health professionals and further research on innovative harm reduction strategies is critically imperative if better service provision is to be delivered in the future.

\section{Declaration of interests}

This work was carried out as part of a dissertation for the Masters in Public Health, University of Manchester. The work was not funded and none of the authors have conflicts of interest.

\section{References}

Aubin, H.-J., Rollema, H., Svensson, T. H., \& Winterer, G. (2012). Smoking, quitting, and psychiatric disease: a review. Neuroscience And Biobehavioral Reviews, 36(1), 271-284. doi:10.1016/j.neubiorev.2011.06.007

Barnett-Page, E., Thomas, J., Barnett-Page, E., \& Thomas, J. (2009). Methods for the synthesis of qualitative research: a critical review. BMC medical research methodology, 9, 59-59. doi:10.1186/1471-2288-9-59

Bittoun, R., Barone, M., Mendelsohn, C. P., Elcombe, E. L., \& Glozier, N. (2014). Promoting positive attitudes of tobacco-dependent mental health patients towards NRT-supported harm reduction and smoking cessation. Aust N Z J Psychiatry, 48(10), 954-956. doi:10.1177/0004867414535673

Bondas, T., \& Hall, E. O. C. (2007). Challenges in approaching metasynthesis research. Qualitative Health Research, 17(1), 113-121.

This article is protected by copyright. All rights reserved. 
Breslau, N., Schultz, L. R., Johnson, E. O., Peterson, E. L., \& Davis, G. C. (2005). Smoking and the risk of suicidal behavior: a prospective study of a community sample. Archives Of General Psychiatry, 62(3), 328-334.

Carson, K. V., Verbiest, M. E., Crone, M. R., Brinn, M. P., Esterman, A. J., Assendelft, W. J., \& Smith, B. J. (2012). Training health professionals in smoking cessation. The Cochrane Library.

CASP, U. (2006). Critical Appraisal Skills Programme (CASP). Qualitative Research.

Conn, V. S., Valentine, J. C., Cooper, H. M., \& Rantz, M. J. (2003). Grey literature in meta-analyses. Nursing Research, 52(4), 256-261.

Davis, K., Brunette, M., Vorhies, V., Ferron, J., \& Whitley, R. (2010). A qualitative study of how individuals with severe mental illness assess smoking risks. Mental Health and Substance Use: Dual Diagnosis, 3(2), 110-123.

Dickerson, F., Bennett, M., Dixon, L., Burke, E., Vaughan, C., Delahanty, J., \& Diclemente, C. (2011). Smoking cessation in persons with serious mental illnesses: the experience of successful quitters. Psychiatric Rehabilitation Journal, 34(4), 311-316. doi:10.2975/34.4.2011.311.316

Emma, B., Ann, M., Paul, A., Jenny, F., Susan, M., \& Robert, W. (2013). Association between use of nicotine replacement therapy for harm reduction and smoking cessation: a prospective study of English smokers. Tobacco control, 22(2), 118-122. doi:10.1136/tobaccocontrol2011-050007

Esterberg, M. L., \& Compton, M. T. (2005). Smoking behavior in persons with a schizophreniaspectrum disorder: a qualitative investigation of the transtheoretical model. Social Science \& Medicine (1982), 61(2), 293-303.

Filia, S. L., Baker, A. L., Gurvich, C. T., Richmond, R., \& Kulkarni, J. (2014). The perceived risks and benefits of quitting in smokers diagnosed with severe mental illness participating in a smoking cessation intervention: Gender differences and comparison to smokers without mental illness. Drug \& Alcohol Review, 33(1), 78-85. doi:10.1111/dar.12091

Fiore, M. C., Keller, P. A., \& Curry, S. J. (2007). Health system changes to facilitate the delivery of tobacco-dependence treatment. American journal of preventive medicine, 33(6), S349-S356.

Forchuk, C., Norman, R., Malla, A., Martin, M.-L., McLean, T., Cheng, S., . . Gibney, C. (2002). Schizophrenia and the motivation for smoking. Perspectives In Psychiatric Care, 38(2), 41-49.

Glaser, B. G., \& Strauss, A. L. (2009). The discovery of grounded theory: Strategies for qualitative research: Transaction publishers.

Green, J. J., \& Thorogood, N. (2009). Qualitative methods for health research.

Hiscock, R., Bauld, L., Amos, A., Fidler, J. A., \& Munafò, M. (2012). Socioeconomic status and smoking: a review. Annals of the New York Academy of Sciences, 1248, 107-123. doi:10.1111/j.1749-6632.2011.06202.x

Hyland, B., Judd, F., Davidson, S., Jolley, D., \& Hocking, B. (2003). Case managers' attitudes to the physical health of their patients. Australian \& New Zealand Journal of Psychiatry, 37(6), 710714.

Johnson, J. L., Moffat, B. M., \& Malchy, L. A. (2010). In the shadow of a new smoke free policy: A discourse analysis of health care providers' engagement in tobacco control in community mental health. International Journal of Mental Health Systems, 4(1), 23.

Jones, M. L. (2004). Application of systematic review methods to qualitative research: practical issues. Journal Of Advanced Nursing, 48(3), 271-278.

Kerr, S., Woods, C., Knussen, C., Watson, H., \& Hunter, R. (2013). Breaking the habit: a qualitative exploration of barriers and facilitators to smoking cessation in people with enduring mental health problems. BMC Public Health, 13, 221-221. doi:10.1186/1471-2458-13-221

Lasser, K., Boyd, J. W., Woolhandler, S., Himmelstein, D. U., McCormick, D., Bor, D. H., . . Bor, D. H. (2000). Smoking and mental illness: A population-based prevalence study. JAMA: Journal of the American Medical Association, 284(20), 2606-2610.

This article is protected by copyright. All rights reserved. 
Lawn, S., \& Condon, J. (2006). Psychiatric nurses' ethical stance on cigarette smoking by patients: determinants and dilemmas in their role in supporting cessation. International journal of mental health nursing, 15(2), 111-118.

Lê Cook, B., Wayne, G. F., Kafali, E. N., Liu, Z., Shu, C., \& Flores, M. (2014). Trends in smoking among adults with mental illness and association between mental health treatment and smoking cessation. Jama, 311(2), 172-182.

Liberati, A., Altman, D. G., Tetzlaff, J., Mulrow, C., Gøtzsche, P. C., loannidis, J. P., . . Moher, D. (2009). The PRISMA statement for reporting systematic reviews and meta-analyses of studies that evaluate health care interventions: explanation and elaboration. Plos Medicine, 6(7), e1000100.

Lucksted, A., Dixon, L. B., \& Sembly, J. B. (2000). A focus group pilot study of tobacco smoking among psychosocial rehabilitation clients. Psychiatric Services (Washington, D.C.), 51(12), 15441548.

Marques de Oliveira, R., \& Furegato, A. R. F. (2014). [The opinion of patients with mental disorder about tobacco and its prohibition in psychiatric hospitalization]. Revista Da Escola De Enfermagem Da U S $P, 48(3), 500-506$.

Mathers, C. D., \& Loncar, D. (2006). Projections of global mortality and burden of disease from 2002 to 2030. Plos Medicine, 3(11), e442-e442.

McNally, L., Oyefeso, A., Annan, J., Perryman, K., Bloor, R., Freeman, S., .. Ghodse, A. H. (2006). A survey of staff attitudes to smoking-related policy and intervention in psychiatric and general health care settings. Journal Of Public Health (Oxford, England), 28(3), 192-196.

Morris, C. D., Waxmonsky, J. A., May, M. G., \& Giese, A. A. (2009). What do persons with mental illnesses need to quit smoking? Mental health consumer and provider perspectives. Psychiatric Rehabilitation Journal, 32(4), 276-284. doi:10.2975/32.4.2009.276.284

Morris, C. D., Waxmonsky, J. A., May, M. G., Tinkelman, D. G., Dickinson, M., \& Giese, A. A. (2011). Smoking reduction for persons with mental illnesses: 6-month results from communitybased interventions. Community Ment Health J, 47(6), 694-702.

Munro, S. A., Lewin, S. A., Smith, H. J., Engel, M. E., Fretheim, A., \& Volmink, J. (2007). Patient adherence to tuberculosis treatment: a systematic review of qualitative research. Plos Medicine, 4(7), e238-e238.

Mwebe, H. (2017). Physical health monitoring in mental health settings: a study exploring mental health nurses' views of their role. J Clin Nurs, 26(19/20), 3067-3078. doi:10.1111/jocn.13653

Nawaz, S., Frounfelker, R., Ferron, J. C., Carpenter-Song, E. A., Davis, K., \& Brunette, M. F. (2012). Smoking and quitting beliefs, attitudes, and behaviors among smokers with severe mental illness from three race/ethnicity groups. Journal Of Dual Diagnosis, 8(3), 180-187.

Prochaska, J. J. (2010). Failure to treat tobacco use in mental health and addiction treatment settings: a form of harm reduction? Drug And Alcohol Dependence, 110(3), 177-182. doi:10.1016/j.drugalcdep.2010.03.002

Prochaska, J. J., Fromont, S. C., Wa, C., Matlow, R., Ramo, D. E., \& Hall, S. M. (2013). Tobacco use and its treatment among young people in mental health settings: a qualitative analysis. Nicotine \& Tobacco Research: Official Journal Of The Society For Research On Nicotine And Tobacco, 15(8), 1427-1435. doi:10.1093/ntr/nts343

Rae, J., Pettey, D., Aubry, T., \& Stol, J. (2015). Factors affecting smoking cessation efforts of people with severe mental illness: a qualitative study. Journal Of Dual Diagnosis, 11(1), 42-49. doi:10.1080/15504263.2014.992096

Robson, D., \& Gray, R. (2007). Serious mental illness and physical health problems: a discussion paper. International Journal of Nursing Studies, 44(3), 457-466.

Sandelowski, M. (2004). Using qualitative research. Qualitative Health Research, 14(10), 1366-1386.

Sharma, R., Meurk, C., Bell, S., Ford, P., \& Gartner, C. (2017). Australian mental health care practitioners' practices and attitudes for encouraging smoking cessation and tobacco harm

This article is protected by copyright. All rights reserved. 
reduction in smokers with severe mental illness. International journal of mental health nursing.

Shiffman, S., Hughes, J. R., Ferguson, S. G., Pillitteri, J. L., Gitchell, J. G., \& Burton, S. L. (2007). Smokers' interest in using nicotine replacement to aid smoking reduction. Nicotine \& Tobacco Research: Official Journal Of The Society For Research On Nicotine And Tobacco, 9(11), 1177-1182.

Snyder, M., McDevitt, J., \& Painter, S. (2008). Smoking cessation and serious mental illness. Archives Of Psychiatric Nursing, 22(5), 297-304. doi:10.1016/j.apnu.2007.08.007

Solway, E. S. (2011). The lived experiences of tobacco use, dependence, and cessation: insights and perspectives of people with mental illness. Health \& Social Work, 36(1), 19-32.

Spring, B., Pingitore, R., \& McChargue, D. E. (2003). Reward value of cigarette smoking for comparably heavy smoking schizophrenic, depressed, and nonpatient smokers. The American Journal Of Psychiatry, 160(2), 316-322.

Stead, L. F., \& Lancaster, T. (2007). Interventions to reduce harm from continued tobacco use. The Cochrane Database Of Systematic Reviews(3), CD005231.

Steinberg, M. L., Williams, J. M., \& Ziedonis, D. M. (2004). Financial implications of cigarette smoking among individuals with schizophrenia. Tobacco control, 13(2), 206-206.

Trainor, K., \& Leavey, G. (2017). Barriers and Facilitators to Smoking Cessation Among People With Severe Mental IIIness: A Critical Appraisal of Qualitative Studies. Nicotine \& Tobacco Research, 19(1), 14-23. doi:10.1093/ntr/ntw183

Zevin, S., \& Benowitz, N. L. (1999). Drug interactions with tobacco smoking. An update. Clinical Pharmacokinetics, 36(6), 425-438.

Ziedonis, D., Hitsman, B., Beckham, J. C., Zvolensky, M., Adler, L. E., Audrain-McGovern, J., . . Riley, W. T. (2008). Tobacco use and cessation in psychiatric disorders: National Institute of Mental Health report. Nicotine \& Tobacco Research: Official Journal Of The Society For Research On Nicotine And Tobacco, 10(12), 1691-1715. doi:10.1080/14622200802443569

This article is protected by copyright. All rights reserved. 
This article has been accepted for publication and undergone full peer review but has not been through the copyediting, typesetting, pagination and proofreading process, which may lead to differences between this version and the Version of Record. Please cite this article as doi:

10.1111/jpm. 12458

This article is protected by copyright. All rights reserved. 


\begin{tabular}{|c|c|c|c|c|c|c|c|}
\hline Authors & Country & $\begin{array}{l}\text { No. } \\
\text { Participants }\end{array}$ & Setting & Demographics & Data collection & Analysis & Key Themes \\
\hline $\begin{array}{l}\text { Davis K, Brunette } \\
\text { M, Vorhies V, } \\
\text { Ferron J, Whitley } \\
\text { R (2010) }\end{array}$ & USA & $\begin{array}{l}31 \text { Service } \\
\text { Users }\end{array}$ & $\begin{array}{l}\text { urban } \\
\text { psychosocial } \\
\text { rehabilitation } \\
\text { agency }\end{array}$ & $\begin{array}{l}17 \text { female } \\
14 \text { male } \\
11 \text { African American, } \\
3 \text { other minority } \\
17 \text { Caucasian }\end{array}$ & One on one interviews & Grounded theory & $\begin{array}{l}\text { Smoking to cope with } \\
\text { symptoms of mental health, } \\
\text { smoking was social activity, } \\
\text { enjoyed smoking } \\
\text { Health effects supported } \\
\text { discussion to quit }\end{array}$ \\
\hline $\begin{array}{l}\text { Dickerson F, } \\
\text { Bennett M, Dixon } \\
\text { L, Burke E, } \\
\text { Vaughan C, } \\
\text { Delanhanty J, } \\
\text { DiClemente C } \\
\text { (2011) }\end{array}$ & USA & $\begin{array}{l}78 \text { Service } \\
\text { Users }\end{array}$ & $\begin{array}{l}\text { outpatient } \\
\text { mental health } \\
\text { services }\end{array}$ & $\begin{array}{l}31 \text { Female } \\
47 \text { Male. } \\
56 \text { Caucasian, } 21 \text { African } \\
\text { American, } 1 \text { other. } \\
\text { Mix diagnoses of mental health } \\
\text { disorders }\end{array}$ & One on one interviews & Descriptive & $\begin{array}{l}\text { Facilitators to quitting: if they } \\
\text { had the social support, } \\
\text { experienced physical health } \\
\text { problems, smoke-free } \\
\text { environments, support from } \\
\text { their health professional }\end{array}$ \\
\hline $\begin{array}{l}\text { Esterberg ML, } \\
\text { Compton MT } \\
\text { (2005) }\end{array}$ & USA & $\begin{array}{l}12 \text { Service } \\
\text { Users }\end{array}$ & $\begin{array}{l}\text { Inpatient } \\
\text { psychiatric } \\
\text { setting and } \\
\text { community } \\
\text { mental health } \\
\text { service }\end{array}$ & $\begin{array}{l}\text { Aged } 19 \text { to } 43 \text { years. } \\
10 \text { male, } 2 \text { female } \\
\text { Range of mental health } \\
\text { disorders, } \\
11 \text { African American, } \\
1 \text { Caucasian }\end{array}$ & One on one interviews & Thematic analysis & $\begin{array}{l}\text { Smoking for mental health } \\
\text { symptoms, reinforcement of } \\
\text { smoking from significant others, } \\
\text { negative attitudes towards NRT, } \\
\text { Lack of confidence in ability to } \\
\text { quit. }\end{array}$ \\
\hline
\end{tabular}

This article is protected by copyright. All rights reserved. 


\begin{tabular}{|c|c|c|c|c|c|c|c|}
\hline $\begin{array}{l}\text { Forchuk C, } \\
\text { Norman R, Malla } \\
\text { A, Martin ML, } \\
\text { McLean T, Cheng } \\
\text { S, Diaz K, } \\
\text { McIntosh E, } \\
\text { Rickwood A, Vos } \\
\text { S, Gibney C } \\
\text { (2002) }\end{array}$ & USA & $\begin{array}{l}100 \text { service } \\
\text { users }\end{array}$ & $\begin{array}{l}\text { Both } \\
\text { inpatients and } \\
\text { outpatients }\end{array}$ & $\begin{array}{l}72 \text { male, } 28 \text { female } \\
\text { Inpatients and community } \\
\text { settings }\end{array}$ & One on one interviews & $\begin{array}{l}\text { Just states } \\
\text { 'qualitative } \\
\text { analysis' }\end{array}$ & $\begin{array}{l}\text { Smoked due to boredom, } \\
\text { smoking helped relaxation, } \\
\text { enjoy smoking }\end{array}$ \\
\hline $\begin{array}{l}\text { Johnson JL, } \\
\text { Moffat B, Malchy } \\
\text { LA (2010) }\end{array}$ & Canada & 91 Staff & $\begin{array}{l}\text { community } \\
\text { mental health } \\
\text { system }\end{array}$ & $\begin{array}{l}42 \text { professionals, } 49 \text { para } \\
\text { professionals. } \\
63 \% \text { Female }\end{array}$ & One on one interviews & $\begin{array}{l}\text { Discourse } \\
\text { analysis }\end{array}$ & $\begin{array}{l}\text { Experience of physical health } \\
\text { problems and cost of tobacco } \\
\text { encourages quit attempts. } \\
\text { Started smoking because of } \\
\text { mental health symptom, culture } \\
\text { of mental health services } \\
\text { encouraged smoking }\end{array}$ \\
\hline $\begin{array}{l}\text { Kerr S, Woods C, } \\
\text { Knussen C, } \\
\text { Watson H, Hunter } \\
\text { R(2013) }\end{array}$ & UK & $\begin{array}{l}27 \text { Service } \\
\text { Users } \\
54 \text { providers }\end{array}$ & $\begin{array}{l}\text { Community } \\
\text { mental health } \\
\text { services }\end{array}$ & $\begin{array}{l}\text { Male } 33 \\
\text { Female } 48 \\
\text { Service users had a mix of } \\
\text { mental health disorders, } \\
\text { majority came from areas of } \\
\text { high deprivation } \\
\text { Providers came from a range of } \\
\text { professional backgrounds }\end{array}$ & One on one interviews & $\begin{array}{l}\text { Framework } \\
\text { analysis }\end{array}$ & $\begin{array}{l}\text { Social norms, using tobacco as a } \\
\text { form of self-medication, the } \\
\text { impact of their mental health } \\
\text { problem, the pleasure/enjoyment } \\
\text { associated with smoking, low } \\
\text { levels of motivation and self- } \\
\text { efficacy and lack of professional } \\
\text { support. } \\
\text { Support from health } \\
\text { professionals was a facilitator to } \\
\text { quitting }\end{array}$ \\
\hline $\begin{array}{l}\text { Lawn S, Condon J } \\
\text { (2006) }\end{array}$ & Australia & 7 Providers & $\begin{array}{l}\text { Inpatient and } \\
\text { community } \\
\text { mental health }\end{array}$ & All qualified clinical nurses & One on one interviews & Thematic analysis & $\begin{array}{l}\text { The right to smoke, Avoidance } \\
\text { disruptive behaviour, too } \\
\text { unwell to quit, did not think it }\end{array}$ \\
\hline
\end{tabular}

This article is protected by copyright. All rights reserved. 


\begin{tabular}{|c|c|c|c|c|c|c|c|}
\hline & & & service & & & & was nurses role \\
\hline $\begin{array}{l}\text { Luckstead AL, } \\
\text { Dixon LB, } \\
\text { Sembly JB (2000) } \\
\end{array}$ & USA & 40 service users & $\begin{array}{l}\text { Rehabilitation } \\
\text { program }\end{array}$ & $\begin{array}{l}28 \text { male, } 12 \text { female } \\
\text { Urban and suburban settings }\end{array}$ & Focus groups & Thematic analysis & $\begin{array}{l}\text { Smoking to help with mental } \\
\text { illness symptoms, smoking } \\
\text { because of boredom, } \\
\text { encouraged to smoke, } \\
\text { environment and social settings } \\
\text { encourages smoking. } \\
\text { Reasons for not smoking - } \\
\text { Health reasons, having a loved } \\
\text { one die from a smoking-related } \\
\text { disease. }\end{array}$ \\
\hline $\begin{array}{l}\text { Marques de } \\
\text { Oliveira R, } \\
\text { Furegato ARF } \\
\text { (2014) }\end{array}$ & Brazil & 96 service users & $\begin{array}{l}\text { Inpatient } \\
\text { psychiatric } \\
\text { ward }\end{array}$ & $\begin{array}{l}59 \text { Female, } 37 \text { Male } \\
\text { Mean age } 38.2 \text { years }\end{array}$ & One on one interviews & Thematic analysis & $\begin{array}{l}\text { Smoking helps with mental } \\
\text { illness symptoms, environment } \\
\text { encourages smoking, bored and } \\
\text { smoking passes the time, } \\
\text { smoking is a social behaviour, } \\
\text { freedom of right to smoke, } \\
\text { would feel unable to cope if } \\
\text { didn't smoke. }\end{array}$ \\
\hline $\begin{array}{l}\text { Morris CD, } \\
\text { Waxmonsky JA, } \\
\text { May MG, Giese } \\
\text { AA (2009) }\end{array}$ & $\overline{\text { USA }}$ & $\begin{array}{l}62 \text { Service } \\
\text { Users } \\
21 \text { Providers }\end{array}$ & $\begin{array}{l}\text { Community } \\
\text { mental health } \\
\text { services }\end{array}$ & $\begin{array}{l}\text { Demographics not record due to } \\
\text { "individual-level data and } \\
\text { subgroup comparisons were not } \\
\text { part of the study }\end{array}$ & Focus group & Thematic analysis & $\begin{array}{l}\text { Staff did not have knowledge or } \\
\text { skills to provide smoking } \\
\text { cessation support. Service users } \\
\text { smoked due to stress, something } \\
\text { to do with their time, to be } \\
\text { social and the environment } \\
\text { encouraged smoking }\end{array}$ \\
\hline $\begin{array}{l}\text { Nawaz S, } \\
\text { Frounfelker R, } \\
\text { Ferron JC, } \\
\text { Carpenter-song }\end{array}$ & $\overline{\text { USA }}$ & $\begin{array}{l}36 \text { Service } \\
\text { Users }\end{array}$ & $\begin{array}{l}\text { Outpatients / } \\
\text { Community } \\
\text { mental health }\end{array}$ & $\begin{array}{l}17 \text { African American, } 12 \text { Latino, } \\
7 \text { white } \\
\text { Range of mental health disorder }\end{array}$ & Focus groups & Iterative process & $\begin{array}{l}\text { Social norm to smoke } \\
\text { Cost of tobacco and physical } \\
\text { health problems were motivators }\end{array}$ \\
\hline
\end{tabular}

This article is protected by copyright. All rights reserved. 


\begin{tabular}{|c|c|c|c|c|c|c|c|}
\hline $\begin{array}{l}\text { EA, Davis K, } \\
\text { Brunette MF } \\
\text { (2012) }\end{array}$ & & & services & diagnosis & & & to quit. \\
\hline $\begin{array}{l}\text { Prochaska JJ, } \\
\text { Fromont SC, Wa } \\
\text { C, Matlow R, } \\
\text { Ramo DE, Hall } \\
\text { SM (2013) }\end{array}$ & USA & $\begin{array}{l}\text { 14 Service } \\
\text { Users } \\
8 \text { Staff }\end{array}$ & $\begin{array}{l}\text { Outpatient } \\
\text { mental health } \\
\text { services }\end{array}$ & $\begin{array}{l}\text { Service Users: } 6 \text { female, } 8 \text { male } \\
\text { Range of mental health } \\
\text { disorders } \\
\text { Providers: All female, range of } \\
\text { professions }\end{array}$ & One on one interviews & Content analysis & $\begin{array}{l}\text { Smokes to relax, Parent } \\
\text { smoking, Other substance use, } \\
\text { boredom, stress, social } \\
\text { acceptance, coping mechanism, } \\
\text { to assert autonomy, mental } \\
\text { health symptoms } \\
\text { More resources for smoking } \\
\text { cessation within services would } \\
\text { encourage cessation }\end{array}$ \\
\hline $\begin{array}{l}\text { Rae J, Pettey D, } \\
\text { Aubry T, Stol J } \\
(2015)\end{array}$ & Canada & $\begin{array}{l}16 \text { Service } \\
\text { Users }\end{array}$ & $\begin{array}{l}\text { Community } \\
\text { mental health } \\
\text { service }\end{array}$ & $\begin{array}{l}8 \text { female } \\
8 \text { male } \\
13 \text { Caucasian, } 2 \text { aboriginal and } 1 \\
\text { black Canadian mixed race. } \\
\text { Mix of diagnosis of mental } \\
\text { health disorders }\end{array}$ & One on one interviews & $\begin{array}{l}\text { Inductive } \\
\text { approach used }\end{array}$ & $\begin{array}{l}\text { Smoked to help with mental } \\
\text { health symptoms, did not want } \\
\text { to quit, did not feel ready to quit } \\
\text { or did not feel could achieve } \\
\text { smoking cessation. }\end{array}$ \\
\hline $\begin{array}{l}\text { Snyder M, } \\
\text { McDevitt J, } \\
\text { Painter S (2008) }\end{array}$ & USA & $\begin{array}{l}25 \text { Service } \\
\text { Users }\end{array}$ & $\begin{array}{l}\text { Psychiatric } \\
\text { rehabilitation } \\
\text { centre }\end{array}$ & $\begin{array}{l}6 \text { female } \\
19 \text { male }\end{array}$ & Focus groups & Iterative process & $\begin{array}{l}\text { Lack of confidence to quit, } \\
\text { social network and environment } \\
\text { encouraged smoking but also if } \\
\text { the right social network and } \\
\text { environment supported quit } \\
\text { attempts. }\end{array}$ \\
\hline Solway ES (2011) & USA & $\begin{array}{l}26 \text { Service } \\
\text { Users }\end{array}$ & $\begin{array}{l}\text { Outpatient } \\
\text { mental health } \\
\text { service }\end{array}$ & $\begin{array}{l}10 \text { Female } \\
16 \text { male }\end{array}$ & $\begin{array}{l}\text { Focus Groups } \\
\text { One interview }\end{array}$ & Grounded theory & $\begin{array}{l}\text { Experience of physical health } \\
\text { problems supported motivation } \\
\text { to quit. }\end{array}$ \\
\hline
\end{tabular}

This article is protected by copyright. All rights reserved. 


\begin{tabular}{|l|l|l|l|l|l|l|}
\hline & & & & $\begin{array}{l}14 \text { white, 10 black, 1 Hispanic, } \\
1 \text { Biracial }\end{array}$ & & $\begin{array}{l}\text { Smoking for mental health } \\
\text { symptoms, used cigarettes as a } \\
\text { form of support }\end{array}$ \\
\hline
\end{tabular}

This article is protected by copyright. All rights reserved. 
Table 2: Analytical themes

\begin{tabular}{|c|c|c|c|}
\hline & $1^{\text {st }}$ Order Constructs & $2^{\text {nd }}$ Order Constructs & Lines of Argument \\
\hline $\begin{array}{l}\text { Provider } \\
\text { Perspectives on } \\
\text { Smoking }\end{array}$ & $\begin{array}{l}\text { Social networks/norms, lack of motivation, low levels of self-efficacy, } \\
\text { prioritisation of mental health over physical health, reluctance to use } \\
\text { mainstream smoking cessation services. Other substance use, social } \\
\text { acceptance, coping mechanism, assert autonomy, mental health, the right } \\
\text { and freedom to smoke, trying to quit whilst they were unwell would } \\
\text { impact on their mental health recovery, not health professionals } \\
\text { role/responsibility, increased risk of violence towards staff if they stopped } \\
\text { service users smoking, Providers don't have knowledge about smoking/ } \\
\text { smoking cessation or the resources }\end{array}$ & $\begin{array}{l}\text { Environment } \\
\text { Social } \\
\text { Living with Mental Health } \\
\text { Disorders }\end{array}$ & \\
\hline $\begin{array}{l}\text { Provider } \\
\text { Perspectives on } \\
\text { facilitators to } \\
\text { Quitting }\end{array}$ & $\begin{array}{l}\text { Physical health, increase of disposable income, support from professional, } \\
\text { Program referral, pharmacotherapy, motivational interviewing, cessation } \\
\text { groups, addressing underlying reasons }\end{array}$ & $\begin{array}{l}\text { Health awareness } \\
\text { Financial awareness } \\
\text { Service structures }\end{array}$ & \\
\hline $\begin{array}{l}\text { Service Users } \\
\text { Perspectives on } \\
\text { Smoking }\end{array}$ & $\begin{array}{l}\text { Social Norms, Self-medication, impact of mental health problem, } \\
\text { pleasure/ enjoyment of cigarettes, low-levels of motivation, low-levels of } \\
\text { self- efficacy, lack of professional support, helps relaxation, parental } \\
\text { smoking, addiction, other substance use, boredom, stress, peer pressure, } \\
\text { able to smoke at home. Normalization of smoking in services, Control over } \\
\text { emotions, no strength to quit, helped to cope with emotions, psychiatric } \\
\text { mediations made them smoke more, would replace it with another } \\
\text { substance, individual choice, social relationships, Providers smoking, } \\
\text { knowledge of smoking /smoking cessation }\end{array}$ & $\begin{array}{l}\text { Environment } \\
\text { Social } \\
\text { Living with Mental Health } \\
\text { Disorders }\end{array}$ & $\begin{array}{l}\text { "Whose role is it anyway?" } \\
\text { Tensions between mental health } \\
\text { service staff perspectives on } \\
\text { their roles and service user } \\
\text { perspectives on their needs to } \\
\text { quit; Lack of knowledge and } \\
\text { awareness leads to inequalities }\end{array}$ \\
\hline
\end{tabular}

This article is protected by copyright. All rights reserved. 


\begin{tabular}{|l|l|l|l|}
\hline $\begin{array}{l}\text { Service Users } \\
\text { Perspectives on } \\
\text { facilitators to }\end{array}$ & $\begin{array}{l}\text { Physical health, cost of smoking, support from professionals, non- } \\
\text { Quitting }\end{array}$ & $\begin{array}{l}\text { judgemental support, physical activity, finding new hobbies, peer support, } \\
\text { education, enforcement of rules, going cold turkey, having never smoked, } \\
\text { health of effects on family, smoke free places, having friends who had } \\
\text { quit, advice from others (professional and family/friends), smoking } \\
\text { restrictions on where they live/work or if they were in hospital, NRT, } \\
\text { cessation group, telephone quitline, Varenicline or Bupropion (smoking } \\
\text { medication), smoking cessation aids }\end{array}$ & Fervice structures \\
& & & \\
& & & \\
& with mental illness. & \\
\end{tabular}

This article is protected by copyright. All rights reserved. 
This article has been accepted for publication and undergone full peer review but has not been through the copyediting, typesetting, pagination and proofreading process, which may lead to differences between this version and the Version of Record. Please cite this article as doi: $10.1111 /$ jpm. 12458

This article is protected by copyright. All rights reserved. 
Table 3: Quality assessment of studies

Results of quality assessment: Credibility

Relevance

\begin{tabular}{|c|c|c|c|c|c|c|c|}
\hline Study & $\begin{array}{l}\text { Data } \\
\text { Collectio } \\
\text { n }\end{array}$ & $\begin{array}{l}\text { Auditabilit } \\
\mathbf{y}\end{array}$ & $\begin{array}{l}\text { Reflexivit } \\
\mathbf{y}\end{array}$ & $\begin{array}{l}\text { Negativ } \\
\text { e Cases }\end{array}$ & $\begin{array}{l}\text { Fair } \\
\text { Dealin } \\
\text { g }\end{array}$ & $\begin{array}{l}\text { Transferabilit } \\
\mathbf{y}\end{array}$ & $\begin{array}{l}\text { Analytic } \\
\text { generalizatio } \\
\text { n }\end{array}$ \\
\hline $\begin{array}{l}\text { Davis et } \\
\text { al } 2010\end{array}$ & Yes & Yes & No & Yes & Yes & Yes & Yes \\
\hline $\begin{array}{l}\text { Dickerso } \\
\text { n et al } \\
2011\end{array}$ & Yes & No & No & No & No & No & Yes \\
\hline $\begin{array}{l}\text { Esterberg, } \\
\text { Compton } \\
2005\end{array}$ & Yes & Yes & No & Yes & Yes & Yes & Yes \\
\hline $\begin{array}{l}\text { Kerr et al } \\
2013\end{array}$ & Yes & Yes & No & Yes & Yes & Yes & Yes \\
\hline $\begin{array}{l}\text { Lawn, } \\
\text { Condon } \\
2006\end{array}$ & Yes & Yes & No & Yes & No & Yes & Yes \\
\hline $\begin{array}{l}\text { Nawaz et } \\
\text { al } 2012\end{array}$ & Yes & Yes & No & Yes & Yes & Yes & Yes \\
\hline $\begin{array}{l}\text { Morris et } \\
\text { al } 2009\end{array}$ & Yes & Yes & No & No & Yes & Yes & Yes \\
\hline $\begin{array}{l}\text { Prochask } \\
\text { a et al } \\
2013\end{array}$ & Yes & Yes & No & Yes & Yes & Yes & Yes \\
\hline $\begin{array}{l}\text { Rae et al } \\
2015\end{array}$ & Yes & Yes & No & Yes & Yes & No & Yes \\
\hline $\begin{array}{l}\text { Snyder et } \\
\text { al } 2008\end{array}$ & Yes & Yes & No & Yes & Yes & Yes & Yes \\
\hline $\begin{array}{l}\text { Solway } \\
2011\end{array}$ & Yes & Yes & No & Yes & Yes & Yes & Yes \\
\hline $\begin{array}{l}\text { Forchuk } \\
\text { C, et al } \\
(2002)\end{array}$ & Yes & Yes & No & No & Yes & Yes & Yes \\
\hline $\begin{array}{l}\text { Marques } \\
\text { de } \\
\text { Oliveira } \\
\mathrm{R}, \\
\text { Furegato } \\
\text { ARF }\end{array}$ & Yes & No & No & No & Yes & No & Yes \\
\hline
\end{tabular}

This article is protected by copyright. All rights reserved. 
(2014)

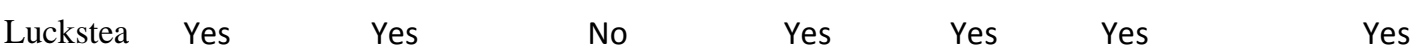

d AL,

Dixon

LB,

Sembly

JB (2000)

This article is protected by copyright. All rights reserved. 
Figure 1: Flowchart of search strategy and selection criteria

From: Moher D, Liberati A, Tetzlaff J, Altman DG, The PRISMA Group (2009). Preferred Reporting Items for Systematic Reviews and MetaAnalyses: The PRISMA Statement. PLoS Med 6(7): e1000097. doi:10.1371/journal.pmed1000097
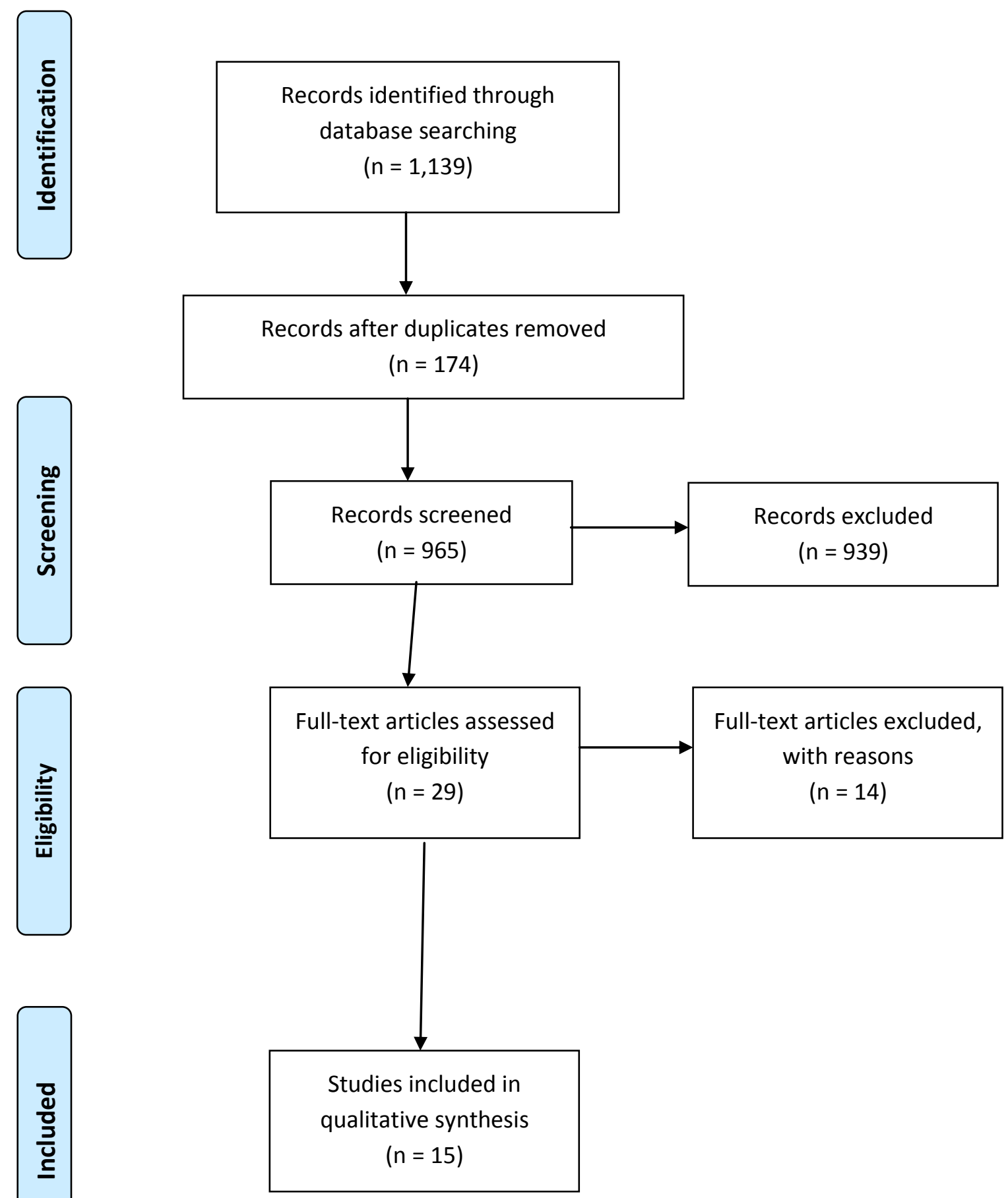

This article is protected by copyright. All rights reserved. 